\title{
Wspólne wartości społeczeństwa holenderskiego
}

Niderlandy mimo niewielkich rozmiarów były i są państwem zamieszkanym przez zróżnicowane społeczeństwo. Wcześniej podziały kształtowały się na kanwie różnic ideologiczno-religijnych przy zachowaniu jednak stosunkowej unitarności etnicznej i kulturowej. Obecnie - po zmniejszeniu się znaczenia religii katolickiej i protestanckiej, a także po napływie imigrantów - podstawą tego zróżnicowania wydaje się być przede wszystkim wielokulturowość.

Celem artykułu jest odpowiedź na pytanie: czy społeczeństwo holenderskie jako całość posiada wspólne dla wszystkich wartości i jeśli tak, to jakie? $\mathrm{W}$ ponowoczesnym, globalnym i wielokulturowym świecie wydaje się mieć ono jednak charakter zdecydowanie bardziej uniwersalny. Jak zauważa Will Kymlicka ${ }^{1}$, obecnie znajdujemy się w dyskursie odwrotu od multikulturalizmu, idąc w stronę poszukiwania tego, co łączy społeczeństwa, narody, i redefiniowania wspólnych wartości. Holandia wydaje się tutaj szczególnie ciekawym przypadkiem z uwagi na to, że jest przykładem kraju, który poniósł porażkę w swojej początkowej polityce wspierania różnorodności i wielokulturowości².

* Dr Magdalena Lipnicka - Katedra Teorii Społecznych i Socjologii Rodziny, Wydział Nauk Społecznych, Katolicki Uniwersytet Lubelski Jana Pawła II, e-mail: magdalena.lipnicka@kul.lublin.pl, ORCID: 0000-0002-1955-6047.

${ }^{1}$ W. Kymlicka, The rise and fall of multiculturalism? New debates on inclusion and accommodation in diverse societies, „International Social Science Journal” 2010, t. 61, nr 199, s. 97-112.

${ }^{2}$ R. Koopmans, Trade-Offs between Equality and Difference. Immigrant Integration, Multiculturalism and the Welfare State in Cross-National Perspective, „Journal of Ethnic and Migration Studies” 2010, t. 36, nr 1, s. 1-26. 
W artykule zostało zaprezentowane zjawisko poszukiwania odpowiedzi na pytanie o wspólne wartości dla społeczeństwa holenderskiego. Holendrzy zwracają się w stronę wartości demokratycznych i związanych z kulturą obywatelską. Opisano również krótko tło historyczne zróżnicowania holenderskiego społeczeństwa i wpływu tej różnorodności na obecną potrzebę definiowania wartości wspólnych, a także dokonano analizy danych empirycznych z holenderskich badań dotyczących wartości.

\section{Wartości jako problem socjologiczny}

Kiedy pytamy o wspólne wartości, staramy się dowiedzieć, czy w danym społeczeństwie są wartości podzielane przez większość bądź takie, co do których ludzie zgadzają się, że są one „ich wartościami”. Niemal każda grupa, naród, każdy okres historyczny i epoka czy dana kultura mają swój zestaw wartości $^{3}$. Na przestrzeni dziejów doszukiwano się również istnienia uniwersalnych wartości, a także próbowano budować różne ich hierarchie. Zajmują się nimi filozofia, psychologia, antropologia, pedagogika i socjologia, a także inne nauki. W zależności od dziedziny i obszaru definicja wartości może być odmienna zaczynając od matematyki i logiki, a kończąc na religii.

Jednym z najbardziej znanych filozofów, który podejmował tematykę wartości, był Max Scheler ${ }^{4}$. Wyróżnił on wartości hedonistyczne, utylitarne, witalne, duchowe (jak np. prawda) i religijne. Zarówno M. Scheler, jak i inny badacz - Józef Tischner - zgadzali się, że wartości można poukładać na skali od najniższych do najwyższych, zakładając, że z wartości niższych jesteśmy w stanie zrezygnować na rzecz tych wyższych (np. hedonizm można poświęcić w imię zdrowia itd.). W ujęciu niemieckiego filozofa wartości nie są jednak tożsame z dobrami, raczej są jakościami idealnymi. Niemniej jednak próba zdefiniowania wartości jest według niego z góry skazana na niepowodzenie ${ }^{5}$. Wartość - zdaniem M. Schelera - najbliższa jest całemu przedmiotowi w „nowej postaci, która jest dana w odczuciu intuicyjnym, tzn. emocjonalnym poznaniu intuicyjnym"6. Przedmiot wartości staje się jednocześnie ich nośnikiem.

${ }^{3}$ Zob. P. Brzozowski, Uniwersalna hierarchia wartości - fakt czy fikcja?, „Przegląd Psychologiczny” 2005, t. 48 , nr 3, s. 261.

${ }^{4}$ Z. Davis, A. Steinbock, Max Scheler, w: The Stanford Encyclopedia of Philosophy (Spring 2019 Edition), red. E.N. Zalta, https://plato.stanford.edu/archives/spr2019/entries/scheler/ (dostęp: 1.02.2020).

${ }^{5}$ M.Wędzińska, Człowiek na drodze do wartości. Myśl etyczna Maxa Schelera - implikacje pedagogiczne, „Przegląd Pedagogiczny” 2013, nr 1, s. 31-43.

${ }^{6}$ M. Scheler, Pisma $z$ antropologii filozoficznej i teorii wiedzy, Wydawnictwo PAN, Warszawa 1987, za: S. Sobczak, Epistemologia wartości Maxa Schelera jako podstawa myślenia pedagogicznego, „Annales Universitatis Mariae Curie-Skłodowska” sec. J 2017, t. 30, nr 3, s. 20. 
Podstawowym pytaniem o definicję wartości jest to, czy można mówić o wartościach obiektywnych (niezależnych od jednostek), czy też są one zawsze subiektywne (są wartością dla kogoś - jednostki lub grupy). Pierwsza socjologiczna definicja wartości została sformułowana przez Thomasa Znanieckiego w Chłopie polskim w Europie i Ameryce w 1921 r. i łączyła elementy obiektywne oraz subiektywne ${ }^{7}$. Zasadniczo jednak za Talcottem Parsonsem i Claydem Kluckhohnem socjologia patrzy na wartości w rozumieniu subiektywnym, jednocześnie podkreślając ich relacjonalny charakter, skupiając się na grupie społecznej jako podmiocie wartości. Grupa może mieć wspólne wartości, mogą jednak także występować duże różnice $\mathrm{w}$ wartościach i przypisywanym im znaczeniu ${ }^{8}$. Ma to także swoje społeczne czy kulturowe uwarunkowania9.

Wartość w ujęciu socjologicznym jest rozumiana m.in. jako coś, co jest pożądane lub godne pożądania. Aspekt ten wybrzmiewa chociażby w definicji C. Kluckhohna: „koncepcja tego, co jest godne pożądania, charakterystyczna dla jednostki lub grupy i wywierająca wpływ na wybór spośród dostępnych sposobów, środków i celów działania"10. Podobnie zdefiniował wartości Stefan Nowak, określając je jako „pewne obrazy i wizje rzeczy, stanów czy procesów pożądanych, uznanych za właściwe, słuszne, czy też takie, jakich by się chciało"”1.

Wartości mogą być przyczynami podejmowania danego działania. Zasadniczo stanowią ważną rolę w systemie przekonań jednostki i wpływają na postawy i dyspozycje zachowań ${ }^{12}$. Mogą wyznaczać cele działań bądź czasem być tylko wyjaśnieniem i „maskować” działania oparte na interesach. Warto jednak zauważyć, że wartość i interes także mogą iść w parze, chociaż bazują na dwóch aspektach - na tym, co jest uważane za słuszne (wartości) i korzystne (interes) ${ }^{13}$.

Ludzie tworzą różne klasyfikacje i hierarchie wartości, które dotyczą różnych sfer życia - od osobistej, rodzinnej po wartości związane ze społeczeństwem, narodem, państwem czy też światem. Większość pragnień i oczekiwań, a więc sądów wartościujących, skupia się na życiu osobistym ludzi, a także na życiu

7 J.L. Spates, The Sociology of Values, „Annual Review of Sociology” 1983, t. 9, s. 27-49.

${ }^{8}$ M. Ziółkowski, Wartości, w: Encyklopedia socjologii, t. 4, red. K.W. Freiske i in., Oficyna Naukowa, Warszawa 2002, s. 289-297.

9 T. Adamczyk, Wartości patriotyczne $w$ doświadczeniu polskich migrantów w Wielkiej Brytanii, „Zeszyty Naukowe KUL” 2019, t. 62, nr 4 (248), s. 71-90.

10 C. Kluckhohnem, Values and value-orientations in the theory of action, w: Towards a General Theory of Action, red. T. Parsons, E. Shills, Harvard University Press, Cambridge 1952, s. 395, tłum. za: M. Ziółkowski, Zmiany systemu wartości, w: Wspótczesne społeczeństwo polskie, red. J. Wasilewski, Wydawnictwo Naukowe Scholar, Warszawa 2006, s. 145.

${ }^{11}$ S. Nowak, Postawy, wartości i aspiracje społeczeństwa polskiego. Przesłanki do prognozy na tle przemian dotychczasowych, w: Społeczeństwo polskie czasu kryzysu. Przeobrażenia świadomości i warianty zachowań, red. S. Nowak, Instytut Socjologii Uniwersytetu Warszawskiego, Warszawa 1984, s. 203, za M. Ziółkowski, Zmiany systemu wartości..., s. 145.

${ }_{12}$ M. Ziółkowski, Wartości..., s. 289-297.

13 Tenże, Zmiany systemu wartości..., s. 145. 
rodzinnym, ewentualnie gronie przyjacielskim ${ }^{14}$. Inną grupą wartości może cechować się poziom narodowy i państwowy, gdzie podmiotem wartości nie jest jednostka, ale społeczeństwo. Według T. Parsonsa wspólne wartości (zinternacjonalizowane i zinstytucjonalizowane) są ważnym elementem strukturotwórczym danej grupy społecznej. Są one także jednym z filarów kohezji ${ }^{15}$. Internacjonalizacja jest procesem wieloetapowym, ale jej punktem wyjściowym jest świadomość istnienia wartości i uznanie ich za własne. Uświadomienie sobie wspólnych wartości jest więc ważne przy podejmowaniu na ich podstawie wspólnych działan' ${ }^{16}$.

Systemy wartości społeczeństw ewoluują dość wolno. Bywają jednak okresy dynamicznych zmian. Zdecydowanie na systemy wartości podzielane przez daną grupę, społeczeństwo czy naród ma wpływ historia (także obce wpływy, wpływy cywilizacyjne, np. związane z cywilizacją europejską, wpływy religii) i kultura. W Polsce wyróżnia się np. wpływ różnych epok, takich jak szczególnie okres zaborów, okres PRL czy transformacji ustrojowej, a także wpływy religii na polską kulturę narodową.

\section{Uwagi metodologiczne}

W niniejszym artykule przyjęto subiektywne, socjologiczne spojrzenie na wartości, których podmiotem jest społeczeństwo niderlandzkie. Podjęto próbę analizy wartości $\mathrm{w}$ tym społeczeństwie z perspektywy i kontekstu ciągłości historycznej. Zbadano, jakie wartości Holendrzy uznają na poziomie deklaratywnym za istotne dla całego społeczeństwa (bez względu na przekonania polityczne czy religijne).

Nie jest możliwe wyjaśnienie wartości dominujących w obecnym społeczeństwie bez sięgnięcia wstecz i zastosowania wyjaśnień o charakterze genetycznym, w związku z tym zaczniemy od krótkiej analizy, pokazując najważniejsze okresy historyczne dla ukształtowania się współczesnego społeczeństwa holenderskiego, wykorzystując do tego typologię Paula Rasora dotyczącą dyskursu tolerancji.

Następnie przeanalizujemy dane współczesne, ograniczając się czasowo do XXI wieku, pochodzące z broszur rządowych (poziom symboliczny), a także raporty z badań empirycznych dotyczących omawianej tematyki. Dane te mają co prawda charakter grupowy i zagregowany, niemniej jednak do celów niniejszej analizy są one całkowicie wystarczające.

${ }^{14}$ S. Nowak, System wartości społeczeństwa polskiego, „Studia Socjologiczne” 1979, nr 4(75), s. $155-173$.

${ }^{15}$ K. Dekker, G. Bolt, Social Cohesion in Post-war Estates in the Netherlands. Differences between Socioeconomic and Ethnic Groups, „Urban Studies” 2005, t. 42, nr 13, s. 2447-2470.

${ }^{16}$ M. Ziółkowski, Wartości..., s. 289-297. 


\section{Historyczne spojrzenie na przemiany wartości w społeczeństwie holenderskim}

Paul Rasor opierając się na raporcie Tolerance and Cultural Diversity Discourses in the Netherlands ${ }^{17}$, w czasie swojego wykładu gościnnego na Uniwersytecie w Groningen ${ }^{18}$ wyróżnił pięć ważnych okresów, które mają wpływ na obecny dyskurs tolerancji w Holandii. Posłużmy się tą typologią, gdyż okresy te są także istotne w kontekście zrozumienia kształtowania się systemu wartości uznawanego obecnie za podstawę społeczeństwa holenderskiego. Wykorzystana zostanie podobna periodyzacja czasowa, jednocześnie jednak nie będziemy skupiać się tylko i wyłącznie na samej tolerancji oraz ocenie tych okresów historycznych (mających również swoje cienie, jak chociażby zaangażowanie Holendrów w kolonializm czy handel niewolnikami), ale uwaga zostanie poświęcona również elementom, które mogły mieć wpływ na obecne deklarowane wartości wspólne w świadomości społecznej i pamięci historycznej.

\section{Okres Republiki (1588-1795)}

Już samo powstanie Królestwa Niderlandów związane było de facto z konfliktem dotyczącym wartości, który splótł się z konfliktem interesów, w tym kwestiami ekonomicznymi. Obszar obecnych Niderlandów znajdował się pod panowaniem hiszpańskiej dynastii Habsburgów. Kwestie ekonomiczne, wolnościowe (przywileje mieszczańskie) i religijne (konflikt na linii katolicka Hiszpania oraz protestanckie Niderlandy) doprowadziły do wybuchu wojny i powstania Republiki Siedmiu Prowincji, która charakteryzowała się wysokim poziomem tolerancji oraz wolności religijnej i światopoglądowej. Duże znaczenie w tamtym okresie miała również warstwa mieszczańska, co w połączeniu z wartościami protestanckimi zapoczątkowało powstanie swoistego etosu mieszczańskiego i obywatelskiego ${ }^{19}$, gdzie istotnymi elementami były np. oszczędność i pracowitość.

${ }^{17}$ M. Maussen, T. Bogers, Tolerance and Cultural Diversity Discourses in the Netherlands, The European University Institute, 2010.

${ }_{18}$ P. Rasor, Hate Speech, Pluralism and the Many Faces of Tolerance, lecture given at the University of Groningen on May 25, 2016, https://soundcloud.com/studium-generale-2/university-colloquium-hate-speech-pluralism-and-the-many-faces-of-tolerance-paul-rasor (dostęp: 17.12.2020).

19 Zob. M.J. ter Voer, Religie en het burgerlljk-kapitalistisch ethos. Een onderzoek naar de relatie tussen religieuze overtuigingen en opvattingen over arbeid, consumptie en eerlijkheid, Instituut voor Toegepaste Sociale wetenschappen, Nijmegen 1994; R.A.M. Aerts, Alles in verhouding. De burgerlijkheid van Nederland, w: De stijl van de burger. Over Nederlandse burgerlijke cultuur vanaf de middeleeuwen, red. R. Aerts H. te Velde, Kok Agora, Kampen 1998, s. 272-300. 


\section{Verzuiling - okres filaryzacji}

Od mniej więcej drugiej połowy XIX w. do ok. 1960 r. holenderskie społeczeństwo było podzielone na filary, tj. katolicy, protestanci, socjaliści i liberałowie. W odróżnieniu od podziału na klasy społeczne, klasyfikacja według filarów ma charakter pionowy, tj. mogą obejmować one kilka klas społecznych. Można to osiągnąć poprzez tworzenie instytucji opartych na filarach, takich jak szkoły, stowarzyszenia, partie, związki zawodowe, rozgłośnie radiowe, gazety i szpitale. Arend Lijphart określa ramy czasowe dla filaryzacji na lata 1917-1967 z uwagi na to, że tzw. schoolstrijd (czyli walka o finansowanie szkół wyznaniowych trwająca od 1848 r.) zakończyła się właśnie w 1917 r. wraz kompromisem społecznym zwanym „Pacificatie”, na którego mocy w 1920 r. przewidziano równe finansowanie dla szkół publicznych i wyznaniowych ${ }^{20}$. Koniec w 1967 r. związany był $\mathrm{z}$ wyborami parlamentarnymi, w których po raz pierwszy znacząco straciły partie katolickie KVP (Katolieke Volkspartij) oraz socjalistyczna PvdA (Partij van de Arbeid) ${ }^{21}$. Oczywiście są to daty umowne, dlatego że samo formowanie się filarów trwało od wieków. Trzy z nich wyłoniły się z rzymskiego katolicyzmu, humanizmu i reformacji ${ }^{22}$. Filary żyły w dość znacznej izolacji społecznej od siebie, a podziały miały także charakter geograficzny, tj. np. katolicy głównie zamieszkiwali południe Holandii, protestanci południowy zachód i środek kraju, socjaliści i liberałowie zaś północne części.

Filaryzacja spowodowała, że holenderska polityka nabrała pewnych charakterystycznych cech, widocznych do tej pory. Jedną z nich była umiejętność współpracy pomimo różnic ideologicznych.

„Polityka pacyfikacyjna była procesem, w którym problemy, które wywołały wielkie napięcia we wzajemnych stosunkach między filarami, zostały jednak rozwiązane w sposób pokojowy. Było to rozstrzyganie sporów, które wydawały się nie do rozwiązania ze względu na ich ideologiczny charakter. Był to proces przywracania pokoju i tworzenia pewnego stopnia konsensusu między filarami, podczas gdy pierwotnie tego nie było. Ważnym wymogiem dla tego rodzaju polityki jest jednak istnienie chociaż minimalnego konsensusu. Poczucie solidarności narodowej w Holandii nie było silne, ale wystarczające, aby oprzeć się odśrodkowym tendencjom filarów. Drugim wymogiem jest to, aby liderzy izolowanych od siebie filarów byli szczególnie świadomi, że polityka musi być prowadzona w ramach obowiązującej konstytucji i że jedność narodowa musi

20 Zob. de Wet op het Lageronderwijs van 1920, http://www.100jaarorthopedagogiek.nl/100jaarPDF/ PDF/Extra/wet-lo-1920-001-202-tekst.pdf (dostęp: 13.09.2021).

21 E.H. Kossmann, Geschiedenis der Nederlandern,deel3. De Lage Landen van 1780 tot 1970, Winkler Prins, Amsterdam/Brussel 1997, s. 320-321.

22 A. Lijphart, Verzuiling, pacificatie en kentering in de Nederlandse politiek, Becht, Haarlem 1990 , s. 29. 
być zachowana pomimo filaryzacji. I ci przywódcy muszą nie tylko chcieć, ale i być w stanie załagodzić spory między filarami” [tłum. - M.L.] ${ }^{23}$.

\section{Rewolucja kulturowa lat sześćdziesiątych}

Lata powojenne w Holandii można podzielić na różne okresy. Pierwszy $\mathrm{z}$ nich to czas zaraz po wojnie, w którym normy i wartości były zbliżone do tych przedwojennych (lata pięćdziesiąte). Drugi okres to czas kryzysu tradycyjnych norm i wartości, wzrostu indywidualizacji i permisywności w obszarze norm i wartości. Nastąpiła także deinstytucjonalizacja i powiązane z nią sekularyzacja oraz defilaryzacja ${ }^{24}$. „W Holandii latach sześćdziesiątych i siedemdziesiątych obchodzono jako wyzwolenie spod filarów. Wszystkie rodzaje wcześniej «dewiacyjnych" zachowań (np. rozwód, homoseksualizm, macierzyństwo bez ślubu) były dozwolone. Nigdy wcześniej tak wielu ludzi nie straciło wiary w tak krótkim czasie (Duyvendak i Koopmans, 1992; Kennedy, 1995 i 2004; Zahn, 1991)" [tłum. - M.L.] ${ }^{25}$.

W latach 1960-1979 spadła liczba katolików (z 37 do 29\%) oraz protestantów (z 10 do $8 \%$ w przypadku Gereformeerde Kerk oraz z 28 na 17\% w przypadku Nederlandse Hervormde Kerk). Na znaczeniu straciły także partie związane $\mathrm{z}$ określonymi filarami ${ }^{26}$. Jest to także okres rewolucji obyczajowej i seksualnej w Holandii. W 1962 r. wprowadzono na holenderski rynek pigułkę antykoncepcyjną, w 1967 r. pojawiła się nagość w telewizji, w 1971 r. uchwalono nowe prawo rozwodowe ${ }^{27}$. W tym okresie w Holandii pojawiają się nowe ruchy społeczne, w tym kontestacyjne i kontrkulturowe, jak chociażby Ruch Provo ${ }^{28}$.

\section{Lata osiemdziesiąte i dziewięćdziesiąte - multikulturalizm}

Kolejnym ważnym (z punktu widzenia obecnego systemu wartości społeczeństwa holenderskiego) procesem jest pojawienie się w Holandii nowych grup narodowościowych i religijnych. Według danych holenderskiego CBS (Centraal

23 Tamże, s. 99.

24 Individualisering in Nederland aan het eind van de twintigste eeuw: empirisch onderzoek naar omstreden hypotheses, red. A. Felling, J. Peters, P. Scheepers, Van Gorcum, Assen 2000, s. 29-30.

25 J.W. Duyvendak, Een eensgezinde vooruitstrevende natie. Over de mythe van 'de' individualisering en de toekomst van de sociologie, Vossiuspers UvA, Amsterdam 2004 (wykład).

26 Individualisering in Nederland aan het eind van de twintigste eeuw..., s. 54.

27 Tamże, s. 20.

28 Zob. R. van Duyn, Provo. De geschiedenis van de provotarische beweging 1965-1967, Meulenhoff, Amsterdam 1985. 
Bureau voor de Statistiek) w październiku 2020 r. w Holandii zamieszkiwało $24,5 \%$ osób z pierwszego lub drugiego pokolenia migrantów (13,9\% osób spoza Europy Zachodniej) ${ }^{29}$. Największe ich grupy stanowili Turcy, Marokańczycy, Niemcy, Polacy, obywatele Surniamu, Indonezji i Antyli Holenderskich.

Migracje do Holandii po II wojnie światowej były związane głównie z dwoma zjawiskami: dekolonizacją (Indie Holenderskie uzyskały niepodległość w 1949 r., Surinam w 1975 r.), a także z potrzebą pracowników tymczasowych (tzw. gastarbaiders). Początkowo byli to przede wszystkim Włosi i Hiszpanie, następnie Turcy i Marokańczycy. W 1974 r. wzrost gospodarczy zwolnił, ale nie zatrzymało to już migracji. Jej poziom wzrastał, m.in. z powodu łączenia rodzin, a pracownicy, którzy mieli być „tymczasowi”, osiedli w Holandii na stałe ${ }^{30}$. Holendrzy na początku nie przywiązywali dużej wagi do polityki integracyjnej (z uwagi na zakładaną tymczasowość migracji), później zaś zastosowali model znany z filaryzacji, tj. założono, że każda z grup stworzy swój „filar”, w związku z czym wspierano podziały i samodzielność organizacyjną mniejszości. Przekonanie takie obowiązywało przede wszystkim w początkowym okresie (do końca lat osiemdziesiątych) i zmniejszyło się w ostatnim dwudziestoleciu XX w. na rzecz skupienia się na emancypacji społeczno-ekonomicznej imigrantów, a następnie ich integracji ${ }^{31}$.

\section{XXI wiek - het liberale intolerantiemodel}

Początek XXI w. to okres zwrotny przede wszystkim w sferze politycznej. $\mathrm{Z}$ jednej strony Holandia w efekcie przemian drugiej połowy XX w. stała się krajem liberalnym, mocno zindywidualizowanym, $z$ drugiej zaś pojawiały się ugrupowania populistyczne i skrajnie prawicowe, jak Lista Pima Fortuyna, którego partia weszła do parlamentu w 2002 r. Karierę polityczną tego polityka przerwało jego zabójstwo z powodów ideologicznych, którego dopuścił się ekolog Volkert van der Graaf. Niedługo później (w 2004 r.) również z pobudek ideologicznych zamordowano Theo van Gogha, antyislamskiego reżysera i publicystę. Oba wydarzenia wstrząsnęły opinią publiczną w Holandii i wpłynęły na holenderską politykę, która do tej pory charakteryzowała się stabilnością

${ }_{29}$ CBS, Hoeveel mensen met een migratieachtergrond wonen in Nederland?, https://www.cbs.nl/ nl-nl/dossier/dossier-asiel-migratie-en-integratie/hoeveel-mensen-met-een-migratieachtergrond-wonen-in-nederland- (dostęp: 19.11.2020).

30 K.S. Prins, Van 'gastarbeider' tot 'Nederlander'. Adaptatie van Marokkanen en Turken in Nederland, b.w., b.m. 1996, s. 2.

${ }^{31}$ M. Hoogenboom, P.W.A. Scholten, Migranten en de erfenis van de verzuiling in Nederland. Een analyse van de invloed van de verzuiling op het Nederlandse migrantenbeleid (circa 1970-heden), "B en M: tijdschrift voor beleid, politiek en maatschappij” 2008, t. 35 nr 2, s. 120. 
i przewidywalnością ${ }^{32}$. Po śmierci P. Fortuyna i rozpadzie jego partii pojawiły się dwa ugrupowania, które próbowały zagospodarować polityczną niszę. „In programmatic terms, this vacuum would consist of a combination of pleas for democratic renewal, a militant civic nationalism, economic liberalism and a preference for restrictive laws on immigration, integration and criminality"33.

O uwagę wyborców zaczęły zabiegać „Trots op Nederland” (na czele z byłą minister Ritą Verdonk) oraz „Partij voor Vrijheid” (na czele z Geertem Wildersem), która ostatecznie zyskała przewagę. Największym sukcesem były wybory w 2009 r., w których PVV zdobyła 24 miejsca w holenderskiej Drugiej Izbie ${ }^{34}$.

$$
* * *
$$

Podsumowując, przemiany społeczne wpływające na systemy norm i wartości społeczeństwa, które dokonały się w Holandii w ostatnich dziesięcioleciach, można scharakteryzować jako przejścia:

a) od filaryzacji do defilaryzacji i sekularyzacji;

b) od kolektywizmu do indywidualizacji, który przejawia się przede wszystkim deinstytucjonalizacją i fragmentaryzacją. W obszarze wartości widać to przede wszystkim we wzroście znaczenia wolności, hedonizmu i ekonomizmu (w znaczeniu utylitarystycznym): „W obszarze orientacji wartości w ciągu ostatnich 25 lat nastąpił wyraźnie proces indywidualizacji: a mianowicie wzrost podstawowej wartości wolności, która wyraża się w silnym wzroście hedonizmu i ekonomizmu w szczególności (rosnący utylitaryzm) oraz osłabieniu familializmu i złagodzenie w dążeniach do politycznej i ekonomicznej równości (upadająca «społeczność»)" [tłum. - M.L.] ${ }^{35}$;

c) od jedności etnicznej do różnorodności - jak stwierdza Jan Willem Duyvendak: „Różnimy się wartościami, stawiając “oświeconych» zachodnich tubylców przeciwko imigrantom, którzy w niewielkim stopniu podzielają te normy i wartości. Równość kobiet i mężczyzn oraz akceptacja homoseksualizmu, obok rozdziału kościoła i państwa, wydają się być papierkiem lakmusowym udanej integracji. (...) Niemniej jednak w Holandii różnica wartości jest większa niż w innych krajach" [tłum. - M.L.] ${ }^{36}$.

32 Zob. I. Buruma, Śmierć w Amsterdamie. Zabójstwo Theo van Gogha igranice tolerancji, TAiWPN Universitas, Kraków 2008.

${ }^{33}$ K. Vossen, Populism in the Netherlands after Fortuyn: Rita Verdonk and Geert Wilders Compared, „Perspectives on European Politics and Society” 2010, t. 11, nr 1, s. 22-38.

${ }_{34}$ Partij voor de Vrijheid (PVV), https://www.parlement.com/id/vhnnmt7m4rqi/partij_voor_ de_vrijheid_pvv (dostęp: 19.11.2020).

${ }^{35}$ Individualisering in Nederland aan het eind van de twintigste eeuw..., s. 16.

${ }^{36}$ J.W. Duyvendak, Een eensgezinde vooruitstrevende natie... 
W związku z tym, że zmiany wpłynęły na społeczeństwo, pojawiła się potrzeba ponownego potwierdzenia i znalezienia wspólnych dla wszystkich Holendrów wartości (nie tylko w sensie narodowym, ale i społecznym, co w powiązaniu ze wspominaną już wielokulturowością oraz rosnącym indywidualizmem wydaje się uzasadnione). Kwestia wspólnych wartości pojawia się co jakiś czas, a szczególnie w czasie niepewności, kiedy trzeba odpowiedzieć na pytanie: co nas właściwie łączy. Zadali je sobie także Holendrzy na początku XXI w.

\section{Wartości deklarowane i uznawane za wspólne w badaniach socjologicznych}

W 2002 r. Wetenschappelijke Raad voor het Regeringsbeleid (dalej: WRR) (RadaNaukowa ds. Polityki Rządu) otrzymała zapytanie od rządu dotyczące tego, jakie fundamentalne wartości łączą holenderskie społeczeństwo, a jakie mogą być konfliktowe, szczególnie w świetle różnic kulturowych. Pokłosiem prac nad tym zagadnieniem był raport Waarden, normen en de last van het gedrag $^{37}$, w którym sformułowano odpowiedź na to pytanie. Chodziło zarówno o sprawdzenie, jakie wartości są podzielane przez społeczeństwo, a także na ile zachowania ludzi są z nimi zgodne (i gdzie oraz dlaczego pojawią się odstępstwa, także w kontekście np. zachowań dewiacyjnych). Założono, że państwo może wspierać wartości demokratyczne i moralność publiczną.

W raporcie podkreślono, że pluralizm wartości sam w sobie nie jest czymś złym. Celem tego sprawozdania (a dalej działań rządowych) jest ustalenie, jak radzić sobie z tymi różnicami. Sam pluralizm wartości nie może także stać $\mathrm{w}$ sprzeczności z autonomią osobistą, równością płci czy możliwością indywidualnego wyboru. Należy więc ustalić, które wartości i normy stają jawnie w sprzeczności z wartościami i normami państwa demokratycznego, a które mogą być (czasowo lub nie) tolerowane ${ }^{38}$.

Autorzy raportu poza sformułowaniem konkretnych zaleceń dla rządu w dziedzinach, takich jak edukacja czy polityka dotycząca pluralizmu, byli zgodni, że: „Istnieje wyraźne i szerokie poparcie dla podstawowych wartości demokratycznego państwa konstytucyjnego (...). Wartości te są niejako wspólnym rdzeniem nowoczesnego otwartego społeczeństwa, które charakteryzuje się wysokim stopniem zindywidualizowanej wolności wyboru obywateli i większą różnorodnością orientacji wartości. Praworządność i demokracja gwarantują ten pluralizm i wolność osobistą. Ponadto są dynamiczne w tym

\footnotetext{
37 WRR, WRR-rapport nr. 68: Waarden, normen en de last van het gedrag', 2003.

38 Tamże, s. 12.
} 
sensie, że wciąż możliwe są nowe interpretacje starych i ustalonych wartości” [tłum. - M.L.] ${ }^{39}$.

Potwierdzono znaczenie takich wartości w społeczeństwie holenderskim jak: pluralizm, indywidualizm, wolność osobista i wolność wyboru, a także prawa człowieka. Jednocześnie jednak spadło znaczenie takich wartości jak dobro wspólne, zaufanie społeczne czy chęć akceptowania i respektowania wartości systemu politycznego. Według autorów raportu rolą rządu i instytucji powinno być więc przede wszystkim wspieranie obywatelskości (należy jednocześnie zachować ostrożność w odniesieniu do wielu rozbieżnych treści związanych $\mathrm{z}$ przekonaniami religijnymi i moralnymi $)^{40}$.

W 2014 r. rząd holenderski wydał publikację Kernawaarden van de Nederlandse samenleving, zgodnie z którą: „W tej broszurze możesz przeczytać o wolności, równości i solidarności. To ważne wartości w naszym społeczeństwie"41. Wskazano również na demokrację, państwo prawa (w tym równość wobec prawa), prawa socjalne, pluralizm (i otwartość społeczną). W dalszej części broszury opisano wolność, równość i solidarność.

Wolność rozumiana jest jako wolność religijna (także do manifestowania swoich uczuć religijnych, ale jednocześnie z zaznaczeniem, że wiara nie zwalnia z przestrzegania prawa), wolność słowa (z zaznaczeniem, że mowa nienawiści nie jest dozwolona), wolność wyboru stylu życia, wolność zrzeszania się, wolność do samostanowienia, która jest rozumiana jako: „W Holandii możesz sam zdecydować, jakich wyborów dokonasz w swoim życiu" ${ }^{42}$. Oznacza to poza wolnościami wymienionymi powyżej, także wolność seksualną, wolność wyboru małżonka i wolność do decydowania o swoim ciele (tutaj także prawo do aborcji i eutanazji).

Równość oznacza, że wszyscy ludzie są równoważni, co jednak nie znaczy, że każdy jest taki sam. „W Holandii ludzie są traktowani jednakowo w takich samych przypadkach. To jest prawo do równego traktowania. Niezależnie od tego, czy jesteś mężczyzną czy kobietą, osobą homoseksualną czy heteroseksualną, młodym czy starym i czy urodziłeś się w Holandii czy w innym kraju. (...) Nie ma odrębnych reguł dla chrześcijan, muzułmanów czy innych wierzących, nie ma też odrębnych reguł dla kobiet czy osób homoseksualnych. (...) Ważne jest, aby osoby niepełnosprawne umysłowo lub fizycznie również mogły uczestniczyć w życiu społecznym [tłum. - M.L.] ${ }^{43}$. W dokumencie przyznano, że mimo takich założeń może dojść do dyskryminacji, podano również co należy zrobić, gdy zaistnieje taka sytuacja.

39 Tamże, s. 264.

40 Tamże, s. 264-265.

${ }^{41}$ Ministerie van Sociale Zaken en Werkgelegenheid, Kernawaarden van de Nederlande samenleving, 2014, s.3.

42 Tamże, s.8.

43 Tamże, s. 9. 
Ostatnią i trzecią wartością omawianą w dokumencie jest solidarność społeczna. Rozumiana jest ona jako wzajemna pomoc, płacenie podatków (bogaci płacą większe podatki), z których finansowane są np. szkoły, działalność społeczeństwa obywatelskiego oraz zabezpieczenia socjalne i gwarantowana płaca minimalna.

W 2016 r. Sociaal en Cultureel Planbureau opracował raport pt. Gedeelde waarden en een weerbare democratie Een verkenning op basis van bevolkingsenquêtes. Podsumowano $\mathrm{w}$ nim wnioski z badań empirycznych dotyczących wartości demokratycznych podzielanych w społeczeństwie holenderskim. Autorzy raportu wyszli z założenia, że takie badanie jest potrzebne, gdyż od jakiegoś czasu w Holandii toczy się dyskusja dotycząca wspólnych wartości, tego, co nas łączy, a także z obawy, że niektóre grupy mogą wypowiadać się przeciw tym wspólnym wartościom. Badanie koncentrowało się na wartościach demokratycznych, przyjmując za model „burżuazyjną kulturę demokratyczną: kulturę obywatelską wspierającą demokrację polityczną, zaangażowanie w społeczeństwo i politykę oraz tolerancję i zaufanie między obywatelami" ${ }^{44}$ oraz fakt, że z badań empirycznych wynika, iż istnieje szerokie poparcie dla takich wartości jak: demokracja, wolność i równość. „Chęć określenia wspólnych wartości może politycznie wynikać głównie z niepewności co do kulturowych podstaw społeczeństwa i rządu, jednocześnie wydaje się, że istnieje duża pewność, że Holendrzy mają coś wspólnego, co odróżnia ich od innych. Począwszy od od kwestii takich jak «towarzyskość», «tolerancja» i «trzeźwość» po akademicką charakterystykę Holandii jako «zjednoczonego narodu postępowego» o stosunkowo jednolitej liberalnej moralnej większości” ${ }^{45}$.

W raporcie autorzy ograniczyli się do wartości związanych $\mathrm{z}$ demokracją i kulturą obywatelską ${ }^{46}$ (zarazem oddzielając te wartości). Jednocześnie rozumieją je szerzej: jako wartości leżące u podstaw społeczeństwa i kultury obywatelskiej, a nie tylko i wyłącznie jako wartości lub preferencje polityczne (czy cele polityczne, jak np. ochrona zdrowia czy zwalczanie ubóstwa). W raporcie nie koncentrowano się również na wartościach osobistych. Autorzy wyszli z założenia, że domeny „społeczna” i „obywatelska” wydają się być właściwym miejscem do poszukiwania wartości wspólnych ( $\mathrm{z}$ uwagi na przywiązanie do etosu obywatelskiego, dużą różnorodność polityczną, religijną i kulturową). Tezą wyjściową było także założenie, że im silniejsza zgoda co do zasad gry politycznej i silniejsze normy tolerancji oraz wiara w dobre intencje innych, tym bardziej możemy się nie zgadzać w kwestiach moralnych i celach politycznych ${ }^{47}$.

44 P. Dekker, J. den Ridder, Gedeelde waarden en een weerbare democratie Een verkenning op basis van bevolkingsenquêtes, Sociaal en Cultureel Planbureau, Den Haag 2016, s. 4.

45 Tamże, s. 7.

46 Tamże, s. 8.

47 Tamże. 
Badanie opierało się po pierwsze na analizie materiałów empirycznych pod kątem przekonań wyrażanych przez samych członków społeczności, a po drugie na analizie danych międzynarodowych w poszukiwaniu wartości, które są szczególne dla Holendrów. Autorzy raportu wykorzystali dane z 9 różnych agencji i jednostek badawczych. Skupiono się na następujących tematach: potrzeba wspólnych wartości, poparcie dla demokracji, znaczenie wolności i równości, cechach dobrego obywatela, a także realnym zaangażowaniu obywatelskim i zaufaniu ${ }^{48}$.

\section{Potrzeba wspólnych wartości}

Dane z badań dotyczących Handvest Verantwoordelijk Burgerschap [Karty Odpowiedzialnego Obywatela] pokazują, że Holendrzy zasadniczo uważają, iż istnieje potrzeba wspólnych wartości w przestrzeni publicznej i postępowanie zgodnie z nimi. Dopuszcza się jednak to, że wartości mogą być ze sobą sprzeczne bądź różnie interpretowane i nie zawsze muszą mieć przełożenie na konkretne zachowania ${ }^{49}$.

\section{Poparcie dla demokracji}

Holendrzy są prawie zgodni, jeśli chodzi o przekonanie, że demokracja jest najlepszą formą rządów. Uważa tak $93 \%$ z nich. Demokracja może być uznana za wartość wspólną dla Holendrów, jest to jednak przekonanie podzielane także przez obywateli innych państw europejskich (w różnej skali). Ludzie łączą demokrację bezpośrednio z wolnością i systemem wybierania władzy przez głosowanie. Pięć najważniejszych cech demokracji dla Holendrów według badania ESS 2012/13 to: 1) wolne i uczciwe wybory; 2) równe traktowanie przez sądy; 3) rząd wyjaśnia swoje decyzje wyborcom; 4) wiarygodne media; 5) sąd może powstrzymać rząd, jeśli wykracza on poza swoje kompetencje. Najważniejsze prawa obywateli dotyczą zaś zapewnienia opieki zdrowotnej dla każdego, dobrego standardu życia obywateli, respektowanie praw mniejszości, poszanowanie prawa demokracji bez względu na okoliczności, więcej możliwości uczestniczenia w podejmowaniu decyzji publicznych ${ }^{50}$.

Jednocześnie Holendrzy zapytani o to, kto mógłby stanąć na czele kraju, wykazują umiarkowane poparcie dla silnych liderów (37\% akceptuje silnego

48 Tamże, s. 9.

49 Tamże, s. 14.

50 P. Dekker, J. den Ridder, Bijlage bij de notitie Gedeelde waarden en een weerbare democratie, SCP, mei 2016, s. 6. 
lidera, który nie musi martwić się o parlament i wybory, a 51\% zaakceptowałoby rządy ekspertów; „Eksperci, a nie rząd, podejmują decyzje na podstawie tego, co uważają za najlepsze dla kraju"). W tym przypadku nie ma konsensusu, niemniej jednak należy zauważyć, że „silne przywództwo” może być pojęciem interpretowanym w różny sposób (zarówno jako rządy autokratyczne, jak i silny lider w ramach demokracji przedstawicielskiej). Co ważne, rządy wojskowych (antydemokratyczna forma rządów) zostały całkowicie odrzucone $(97 \%)^{51}$.

\section{Wolność i równość}

W badaniu Eurobarometr z 2015 r. Holendrzy wybrali trzy najważniejsze wartości z dwunastu i były to: równość, tolerancja i praworządność. Na dole listy znalazły się religia, szanowanie innych kultur oraz rozwój osobisty. W badaniu przeprowadzonym przez agencję badawczą Veldkamp z 2010 r. należało wybrać trzy wartości z listy ośmiu. Najwyższe wartości uzyskały: „Docenianie ludzi”, „Zabieranie głosu”, „Podejmowanie decyzji na podstawie argumentów”"52. Wybierając pomiędzy wolnością a równością, Holendrzy opowiadają się za wolnością (62 do $37 \%)^{53}$.

Szczególną uwagę poświęcono wolności wypowiedzi, która jest wartością powszechnie uznawaną, istnieje silne poparcie dla wolności demonstracji (94\%), krytyki rodziny królewskiej (wzrost z 54\% w 1970 r. do 94\% w 2009 r.). Jest także silne poparcie dla wolności wypowiedzi publicznych (76\%). Jednocześnie jednak $37 \%$ osób uważa, że w niektórych sytuacjach prawo do wolności wypowiedzi może być ograniczone. 69\% Holendrów uznaje jednak prawo do wyrażania także skrajnych poglądów politycznych i w porównaniu z innymi państwami Europy zajmuje średnią pozycję. Z badań Veldkamp z 2010 r. wynika ponadto, że 70\% Holendrów uważa, że wolność słowa i wolność religijna uzupełniają się nawzajem. Obserwowany jest jednak spadek poparcia dla pełnej wolności religijnej w porównaniu z latami osiemdziesiątymi XX w. (szczególnie wobec muzułmanów) ${ }^{54}$.

Równe traktowanie jest pojęciem szerokim, bo dotyczy różnych aspektów (płci, wieku, orientacji, pochodzenia itp.).Co prawda, np. 94\% Holendrów opowiada się za pełną tolerancją wobec osób homoseksualnych. Jednak dane $\mathrm{z}$ innych badań pokazują, że $84 \%$ ankietowanych Holendrów spotyka się często z dyskryminacją ze względu na pochodzenie etniczne, $66 \%$ - religię lub przekonania, 64\% - orientację seksualną, co oznacza, że istnieją duże wątpliwości,

\footnotetext{
51 Tamże, s. 18. Dla porównania są one akceptowalne np. w 30\% w Turcji czy w 17\% w Rosji.

52 Tamże, s. 20-21.

53 P. Dekker, J. den Ridder, Bijlage bij..., s. 16.

54 Tamże, s. 22.
} 
czy niedyskryminacja jest faktycznie zakorzenioną wspólną wartością, oraz na ile wartość deklarowana jest faktycznie wartością podzielaną i realizowaną.

\section{Cechy dobrego obywatela}

Zapytani o cechy dobrego obywatela Holendrzy wskazują przede wszystkim na to, że dobrym obywatelem jest ktoś, kto dba o siebie, nie jest ciężarem dla innych, a także nie oszukuje, a mówiąc inaczej - jest pomocny i zaangażowany społecznie, zwłaszcza we własnym środowisku lokalnym. Wartości te plasowały się z dala zarówno od polityki, jak i od życia prywatnego. Obywatelstwo dla Holendrów ma związek z relacjami z innymi osobami w społeczeństwie. Duże znaczenie ma także etyka, którą należy się kierować na co dzień. Za trzy podstawowe cechy dobrego obywatela (w badaniach SCP z 2004 r.) uznano solidarność z innymi (48\%), pozytywna postawę wobec innych ludzi i brak dyskryminacji $(37 \%)$ oraz przestrzeganie prawa $(35 \%)^{55}$.

\section{Realne zaangażowanie obywatelskie i poziom zaufania}

Holendrzy wykazują się wysokim poziomem zaufania społecznego. W badaniach z 2014 r. 94\% ufa parlamentowi, 96\% - wymiarowi sprawiedliwości (porównując: w Polsce jest to 67 i 66\%). 50\% Holendrów darzy innych ludzi zaufaniem (analogicznie 16\% Polaków). Holendrzy plasują się też wysoko, jeśli chodzi o poziom zaangażowania obywatelskiego $(60 \% \text {, w Polsce } 39 \%)^{56}$.

\section{Wnioski}

Holandia była od momentu jej powstania państwem zróżnicowanym, najpierw religijnie, następnie religijno-ideologicznie, a od lat osiemdziesiątych XX w. także etnicznie. Pluralizm i etos mieszczański były podstawami, na których oparła się młoda Republika. Wartości te jeszcze bardziej uwidoczniły się w trakcie filaryzacji, a w drugiej połowie XX w. nabrały nowego znaczenia. Społeczeństwo w okresie intensywnych przemian spotkało się ponadto z problemem rosnącego zróżnicowania kulturowego i etnicznego oraz kryzysem wynikającym z multikulturalizmu. Spowodowało to potrzebę odpowiedzi na pytanie: „Co nas właściwie łączy jako społeczeństwo holenderskie”? Z uwagi na ogromne

\footnotetext{
55 Tamże, s. 21.

56 Tamże, s. 23-25.
} 
zróżnicowanie społeczne (polityczne, ideologiczne, religijne), a także powrót do korzeni i podstaw państwa (etosu mieszczańskiego) poszukiwanie odpowiedzi na to pytanie i wspólnej płaszczyzny porozumienia w sferze obywatelskości i wartości demokratycznych wydaje się uzasadnione.

Broszura Kernawaarden van de Nederlandse samenleving, która jest dostępna na stronie rządu holenderskiego, jasno wskazuje na: wolność, równość i solidarność jako podstawowe wartości. Znajduje to częściowe potwierdzenie $\mathrm{w}$ badaniach empirycznych, chociaż z naciskiem na dużo większe znaczenie wolności, wraz z solidarnością, praworządnością i zaangażowaniem obywatelskim. Równość rozumiana jest bardziej jako tolerancja wobec innych i brak dyskryminacji. Wolność zaś uznawana jest za wartość stojącą wyżej - zarówno wolność do samostanowienia o sobie i swoim życiu (czego efektem jest chociażby wprowadzenie regulacji odnośnie do aborcji czy eutanazji), jak i wolność wypowiedzi (stojąca wyżej niż obraza uczuć religijnych), czy możliwość krytyki autorytetów i władzy, jak np. rodziny królewskiej. Ograniczenie władzy rządu (w przypadku nadużyć) i pełna niezawisłość sądów jest również ważnym aspektem demokracji dla Holendrów. Ma to związek z pragmatycznym i krytycznym podejściem do świata. Warto także zauważyć, że Holendrzy zasadniczo cechują się wysokim poziomem zaufania społecznego do instytucji demokratycznych i do współobywateli, a także zaangażowaniem w sprawy publiczne, co zdecydowanie może dodatkowo (i wzajemnie) wzmacniać znaczenie kultury obywatelskiej i demokratycznej.

Wartości, które zostały opisane w artykule, są oczywiście uznawane na poziomie przekonań i opinii (deklaratywne) i nie wiemy, na ile rzeczywiście kształtują normy konkretnych zachowań jednostek. W samych badaniach nie zawsze znajdujemy spójne przekonania, np. warto zauważyć, że pomimo deklarowania tolerancji jako ważnej wartości wielu badanych wskazuje na spotykanie się z dyskryminacją. Rzeczywistość także bywa różna, co widać w nastawieniu antyimigracyjnym niektórych partii politycznych (oraz ich poparciu), a także w praktyce społecznej (napięcia społeczne i trudności związane $\mathrm{z}$ wielokulturowością, wieloreligijnością i migracjami).

\section{Bibliografia}

Adamczyk T., Wartości patriotyczne w doświadczeniu polskich migrantów w Wielkiej Brytanii, „Zeszyty Naukowe KUL" 2019, t. 62, nr 4 (248), s. 71-90, DOI: 10.31743/zn.2019.62.4.04.

Aerts R.A.M., Alles in verhouding. De burgerlijkheid van Nederland, w: „De stijl van de burger. Over Nederlandse burgerlijke cultuur vanaf de middeleeuwen", red. A. Remieg, H. Te Velde, Kok Agora, Kampen 1998, s. 272-300.

Brzozowski P., Uniwersalna hierarchia wartości - fakt czy fikcja?, „Przegląd Psychologiczny” 2005, t. $48, \mathrm{nr} 3$, s. 261-276. 
Buruma I., Śmierć w Amsterdamie. Zabójstwo Theo van Gogha i granice tolerancji, tłum. A. Lipszyc, TAiWPN Universitas, Kraków 2008.

CBS, Hoeveel mensen met een migratieachtergrond wonen in Nederland?, https://www.cbs.nl/nl-nl/ dossier/dossier-asiel-migratie-en-integratie/hoeveel-mensen-met-een-migratieachtergrond-wonen-in-nederland- (dostęp: 19.11.2020).

Davis Z., Steinbock A., Max Scheler, The Stanford Encyclopedia of Philosophy (Spring 2019 Edition), red. E.N. Zalta, https://plato.stanford.edu/archives/spr2019/entries/scheler/ (dostęp: 1.02.2020).

De Wet op het Lageronderwijs van 1920, http://www.100jaarorthopedagogiek.nl/100jaarPDF/PDF/ Extra/wet-lo-1920-001-202-tekst.pdf (dostęp: 13.09.2021).

Dekker P., Ridder den J., Bijlage bij de notitie Gedeelde waarden en een weerbare democratie, SCP, mei 2016, https://www.scp.nl/binaries/scp/documenten/publicaties/2016/05/03/gedeelde-waarden-en-een-weerbare-democratie/Bijlagen+Gedeelde+waarden+en+een+weerbare +democratie_DEF_mei.pdf (dostęp: 1.02.2020).

Dekker P., Ridder den J., Gedeelde waarden en een weerbare democratie. Een verkenning op basis van bevolkingsenquêtes, Sociaal en Cultureel Planbureau, Den Haag 2016, https://www.scp. $\mathrm{nl} /$ binaries/scp/documenten/publicaties/2016/05/03/gedeelde-waarden-en-een-weerbare-democratie/Gedeelde+waarden+en+een+weerbare+democratie.pdf (dostęp: 1.02.2020).

Duyn van R., Provo. De geschiedenis van de provotarische beweging 1965-1967, Meulenhoff, Amsterdam 1985.

Duyvendak J.W., Een eensgezinde vooruitstrevende natie: over de mythe van 'de' individualisering en de toekomst van de sociologie, Vossiuspers UvA, Amsterdam 2004 (wykład).

Individualisering in Nederland aan het eind van de twintigste eeuw. Empirisch onderzoek naar omstreden hypotheses, red. A. Felling, J. Peters, P. Scheepers, Van Gorcum, Assen 2000.

Hoogenboom M., Scholten P.W.A., Migranten en de erfenis van de verzuiling in Nederland. Een analyse van de invloed van de verzuiling op het Nederlandse migrantenbeleid (circa 1970-heden), „B en M: tijdschrift voor beleid, politiek en maatschappij” 2008, t. 35, nr 2, s. 107-124.

Koen V., Populism in the Netherlands after Fortuyn. Rita Verdonk and Geert Wilders Compared, „Perspectives on European Politics and Society" 2010, t. 11, nr 1, s. 22-38.

Koopmans R. Trade-Offs between Equality and Difference. Immigrant Integration, Multiculturalism and the Welfare State in Cross-National Perspective , ,Journal of Ethnic and Migration Studies" 2010, t. 36, nr 1, s. 1-26.

Kossmann E.H., Geschiedenis der Nederlanden, deel 3: De Lage Landen van 1780 tot 1970, Winkler Prins, Amsterdam/Brussel 1977, s. 320-321.

Kymlicka W., The rise and fall of multiculturalism? New debates on inclusion and accommodation in diverse societies, „International Social Science Journal” 2010, t. 61, nr 199, s. 97-112.

Lijphart A., Verzuiling, pacificatie en kentering in de Nederlandse politiek, Becht, Haarlem 1990.

Maussen M., Bogers T., Tolerance and Cultural Diversity Discourses in the Netherlands, The European University Institute, b.m. 2010.

Ministerie van Sociale Zaken en Werkgelegenheid, Kernawaarden van de Nederlandse samenleving, 2014. https://www.rijksoverheid.nl/documenten/brochures/2014/05/21/kernwaarden-nederland (dostęp: 13.09.2021).

Nowak S., System wartości społeczeństwa polskiego, „'Studia Socjologiczne” 1979, nr 4(75), s. 155-173.

Partij voor de Vrijheid (PVV), https://www.parlement.com/id/vhnnmt7m4rqi/partij_voor_de_vrijheid_pvv (dostęp: 19.11.2020).

Prins K.S. Van 'gastarbeider' tot 'Nederlander': adaptatie van Marokkanen en Turken in Nederland, b.w., b.m. 1996.

Rasor P., Hate Speech, Pluralism and the Many Faces of Tolerance, lecture given at the University of Groningen on May 25, 2016, https://soundcloud.com/studium-generale-2/university-colloquium-hate-speech-pluralism-and-the-many-faces-of-tolerance-paul-rasor (dostęp: 17.12.2020). 
Sobczak S., Epistemologia wartości MaxaSchelera jako podstawa myślenia pedagogicznego „Annales Universitatis Mariae Curie-Skłodowska" sec. J 2017, t. 30, nr 3, s. 17-26, DOI: 10.17951/j.2017.30.3.17.

Voerter M.J, Religie en het burgerlljk-kapitalistisch ethos. Een onderzoek naar de relatie tussen religieuze overtuigingen en opvattingen over arbeid, consumptie en eerlijkheid, Instituut voor Toegepaste Sociale wetenschappen, Nijmegen 1994.

Wędzińska M., Człowiek na drodze do wartości Myśl etyczna MaxaSchelera - implikacje pedagogiczne , „Przegląd Pedagogiczny" 2013, nr 1, s. 31-43.

WRR, WRR-rapport nr. 68: Waarden, normen en de last van het gedrag', Amsterdam University Press, Amsterdam 2003.

Ziółkowski M., Zmiany systemu wartości, w: Współczesne społeczeństwo polskie. Dynamika zmian, red. J. Wasilewski, Wydawnictwo Naukowe Scholar, Warszawa 2006, s. 145-171.

\section{Streszczenie}

Z uwagi na coraz większą wielokulturowość oraz przemiany społeczno-ideologiczne w Niderlandach pojawiła się potrzeba zdefiniowania wspólnych wartości dla całego społeczeństwa. W artykule wartości te są analizowane z dwóch perspektyw - przemian historycznych (ok. okresu powstania Republiki, poprzez filaryzację, przemiany lat sześćdziesiątych aż po czasy obecne) oraz stanu obecnego w oparciu $o$ analizę danych zastanych, w tym $z$ badań empirycznych. Na podstawie przeprowadzonej analizy można uznać, że Holendrzy za swoje wartości wspólne uznają wartości związane z kulturą obywatelską i demokratyczną, w tym m.in. wolność, równość i solidarność.

Słowa kluczowe: socjologia wartości, Niderlandy, wartości demokratyczne, filaryzacja

\section{Common Values of the Dutch Society}

\section{Summary}

Due to the growing multiculturalism and socio-ideological changes in the Netherlands, there has emerged a need to define common values for the whole society. In the article, these values are analysed from two perspectives: historical changes (since the time the Republic was founded, through the pillarisation, and the transformation of the 1960s to the present day) and the current status quo, analysed with empirical research data. The analyses conducted in the article allow the conclusion that the Dutch society shares values related to civic and democratic culture, including freedom, equality and solidarity.

Key words: sociology of values, the Netherlands, democratic values, pillarisation 